\title{
ANALISIS POLA PENGGUNAAN RUANG DAN WAKTU ORANGUTAN (Pongo pygmaeus pygmaeus Linneaus, 1760) DI HUTAN MENTOKO TAMAN NASIONAL KUTAI, KALIMANTAN TIMUR (Spatial Pattern Distribution Analysis of Orangutan (Pongo pygmaeus pygmaeus Linnaeus, 1760) in Mentoko Forest, Kutai National Park, East Kalimantan)*)
}

Oleh/By:

Yanto Santosa ${ }^{1}$, Agustinus Krisdijantoro ${ }^{2}$, Machmud Thohari ${ }^{1}$ dan/and Dede Aulia Rahman $^{1}$

${ }^{1}$ Laboratorium Ekologi Satwaliar, Departemen Konservasi Sumberdaya Hutan dan Ekowisata, Fakultas Kehutanan IPB, Kampus IPB Darmaga, Kotak Pos 168 Bogor 16001-Indonesia, Telp/Fax 62-251-86247661 e-mail: rahman_abelii@yahoo.co.id

${ }^{2}$ Balai Taman Nasional Kelimutu; Jln. El Tari No.16 Ende, Flores-Nusa Tenggara Timur

*)Diterima : 28 Desember 2010; Disetujui : 22 September 2011

\begin{abstract}
Increasing rate of forest degdradation influences orangutan habitat to become more narrow. Conservation efforts can be done through the management of its remaining habitat, therefore ecological and quantitative aspects of orangutan become the interest of this study. This research was carried out in Mentoko Forest of Kutai National Park, East Kalimantan. The methodology of this research covered both observation of orangutan behaviour and vegetation analysis of orangutan habitat. The objectives of this research, are to find out the use of spatial pattern of wild orangutan, to observe of time pattern and rhitmic activity of the orangutan in their natural habitat. The result, of this research are that orangutan in Mentoko prefers to run their activities on 20-30 meters high from the ground, spending time for diets is average of 44.4\% of their whole activities, $39.2 \%$ for rest, $11 \%$ movement activity, and $5.4 \%$ for others. Composition of vegetation in their habitat shows that there are 51 mature trees with Shannon index of 3.75 covered 25 family, 36 poles stage of 19 family and 39 saplings species of 22 family.
\end{abstract}

Keywords: Orangutan, population, natural habitat, activity, Mentoko forest, Kutai National Park

\begin{abstract}
ABSTRAK
Peningkatan kerusakan hutan menyebabkan semakin sempitnya habitat orangutan dan diantara upaya konservasi yang dapat dilakukan adalah pengelolaan habitat yang tersisa berdasarkan aspek ekologi orangutan dan kuantitatifnya. Penelitian ini dilakukan di Mentoko, Taman Nasional Kutai, Kalimantan Timur, meliputi penelitian perilaku orangutan dan analisis vegetasi habitat orangutan. Penelitian bertujuan untuk mengetahui pola penggunaan spasial dan pola penggunaan waktu serta ritme orangutan dalam habitat alami. Hasil penelitian menunjukkan bahwa presentase aktivitas harian orangutan di Mentoko lebih banyak berada pada ketinggian 20-30 meter dari tanah dan rata-rata 44,4\% dari seluruh kegiatan mereka dihabiskan untuk aktivitas makan, 39,2\% untuk istirahat, $11 \%$ aktivitas bergerak, dan 5,4\% untuk aktivitas lainnya. Pada kondisi yang ideal tanpa gangguan, penggunaan habitat terkait ketinggian orangutan dalam beraktivitas cenderung bervariasi dari posisi rendah sampai tinggi sesuai posisi sumber pakan. Sebaliknya apabila kondisi tidak aman maka akan beraktivitas pada tempat yang lebih tinggi. Pilihan ketinggian posisi untuk membuat sarang, selama pengamatan ketinggian rata-rata dalam membuat sarang lebih dari 20 meter dimana sebenarnya pada kondisi tanpa pengamatan, orangutan seringkali membuat sarang pada ketinggian 8-10 meter dari permukaan tanah dalam penggunaan ruang, orangutan melakukan regenerasi antara 0,65-1,11 km adalah habitat yang terdiri dari 51 jenis pohon dengan indeks keanekaragaman jenis 3,75 yang terdiri atas 25 famili, 36 spesies pada tingkat pertumbuhan tiang dari 19 famili dan 39 spesies pada tingkat pertumbuhan anakan dari 22 famili.
\end{abstract}

Kata kunci: Orangutan, populasi, habitat alami, aktivitas, Hutan Mentoko, Taman Nasional Kutai

\section{PENDAHULUAN}

Orangutan (Pongo pygmaeus pygmaeus Linnaeus, 1760) pada saat ini hanya ada di Sumatera, Kalimantan, Sabah, dan
Serawak dan lebih dari $90 \%$ habitatnya berada di wilayah Indonesia. Laju degradasi hutan di Sumatera dan Kalimantan yang terus meningkat menyebabkan 
semakin sempitnya habitat orangutan (Meijaard et al., 1999). Pada waktu kebakaran hutan tahun 1997/1998 kurang lebih sepertiga dari jumlah orangutan liar mati. Tersisa kira-kira 12.000 sampai 15.000 ekor orangutan di Pulau Kalimantan (dibandingkan dengan 20.000 pada tahun 1996), dan kira-kira 4.000 sampai 6.000 di Sumatera (dibandingkan dengan 10.000 pada tahun 1996). Menurut taksiran para ahli, orang utan liar bisa menjadi punah dalam jangka waktu sepuluh tahun lagi (Meijaard dan Makinudin, 2007).

Upaya pelestarian orangutan dapat dilakukan melalui pengelolaan habitat yang tersisa, karena itu pengetahuan ekologi dan data kuantitatif mutlak diperlukan. Pengetahuan ekologi orangutan dapat diperoleh melalui pengamatan perilakunya di habitat alami. Data kuantitatif orangutan masih sangat terbatas, penilaian populasi dan kerapatan per satuan luas sampai saat ini hanya melalui pendekatan penghitungan jumlah sarang, karena untuk menemukan orangutan liar sangat sulit. Oleh karena itu untuk menggali informasi tersebut, dilakukan penelitian mengenai interaksi orangutan dengan habitatnya melalui pendekatan analisis bagaimana orangutan liar menggunakan ruang dan waktu di hutan Mentoko Taman Nasional Kutai, Kalimantan Timur. Pola penggunaan ruang merupakan keseluruhan interaksi antara satwa dengan habitatnya. Pola penggunaan waktu adalah pengalokasian waktu untuk setiap aktivitas hariannya. Tujuan penelitian ini adalah untuk mengetahui pola penggunaan ruang, pola penggunaan waktu, dan ritme aktivitas orangutan di habitat alaminya. Manfaat yang diharapkan dari hasil penelitian ini adalah dapat menjadi acuan dalam pengelolaan habitat orangutan, acuan dalam penyusunan metode kuantitatif mengenai orangutan, dan masukan bagi pengelola Taman Nasional Kutai dalam upaya pelestarian orangutan.

\section{BAHAN DAN METODE}

\section{A. Waktu dan Lokasi Penelitian}

Penelitian dilakukan pada bulan Mei sampai dengan Juni 2007 di kawasan hutan Mentoko, Taman Nasional Kutai, Kalimantan Timur.

\section{B. Bahan dan Alat Penelitian}

Obyek penelitian adalah lima individu orangutan kalimantan yang terdiri dari dua jantan dewasa umur muda, dua betina dewasa umur muda, dan satu ekor anak. Bahan yang digunakan meliputi alkohol, kantong plastik, label kertas, dan tali plastik. Alat penelitian yang digunakan dalam penelitian meliputi meteran dengan panjang $25 \mathrm{~m}$, binokuler, tustel, GPS, kompas, haga meter, hand counter, jam, peralatan herbarium, dan alat tulis.

\section{Metode Pengumpulan Data}

Data yang dikumpulkan meliputi:

1. Perilaku orangutan (makan, istirahat, bergerak, dan aktivitas lainnya), penggunaan waktu dan ruang dalam beraktivitas. Data dikumpulkan melalui pengamatan secara langsung terhadap aktivitas harian orangutan mulai keluar sarang untuk memulai aktivitas sampai membuat sarang untuk tidur pada sore hari. Parameter yang diamati adalah jenis pohon dan ketinggian orangutan di atas pohon, jenis, bagian-bagian pohon yang dimakan orangutan, lama waktu orangutan melakukan aktivitas, waktu orangutan melakukan setiap jenis aktivitas, pola pergerakan orangutan, komposisi vegetasi secara umum, dan vegetasi pakan.

2. Vegetasi tempat orangutan beraktivitas, menggunakan Metode Petak Tunggal (Soerianegara dan Indrawan, 1984). Petak contoh dibuat sebanyak dua buah diletakkan secara purposive sampling masing-masing pada lokasi di mana kelompok/individu orangutan beraktivitas. Petak contoh berukuran 
lebar $40 \mathrm{~m}$ dan panjang $80 \mathrm{~m}$. Parameter yang diukur secara langsung di lapangan adalah nama spesies (lokal dan ilmiah), jumlah individu, dan diameter pohon pada ketinggian setinggi dada.

\section{Analisis Data}

Data yang diperoleh dari pengamatan dianalisis secara diskriptif, kuantitatif, dan uji Khi-kuadrat $\left(\chi^{2}\right)$.

\section{Analisis Perilaku}

Untuk mengetahui hubungan habitat dengan perilaku orangutan digunakan Uji Khi-kuadrat. Hubungan-hubungan dimaksud di antaranya adalah:

a. Jenis aktivitas dengan posisi dalam ruang (ketinggian pada pohon/vegetasi).

b. Jenis aktivitas pada posisi tertentu dalam ruang dengan waktu.

c. Jenis aktivitas dengan waktu.

Hipotesa-hipotesa yang diuji sebagai

$\mathrm{H}_{0}$ adalah:

a. Tidak adanya hubungan antara aktivitas tertentu yang dilakukan orangutan dengan ketinggian pohon.

b. Penggunaan waktu oleh semua individu adalah sama.

c. Penggunaan waktu oleh semua individu pada setiap kelas ketinggian pada pohon adalah sama.

Untuk menguji hipotesis nol $\left(\mathrm{H}_{0}\right)$ dengan cara menghitung semua frekuensi harapan bagi setiap sel. Pengujian hipotesa menggunakan rumus:

$$
x=\sum \frac{\left(\mathrm{O}_{\mathrm{i}}-\mathrm{E}_{\mathrm{i}}\right)^{2}}{\mathrm{E}_{\mathrm{i}}}
$$

Dimana:

$\mathrm{O}_{\mathrm{i}}=$ Frekuensi hasil pengamatan ke-i

$\mathrm{E}_{\mathrm{i}}=$ Frekuensi yang diharapkan

Pengujian dilakukan dengan $\chi^{2}$ tabel pada tingkat signifikan 0,05 . Jika $\chi^{2}$ hitung $>\chi^{2}$ $\alpha$, maka tolak $\mathrm{H}_{0}$ dan jika $\chi_{\text {hitung }}^{2}<\chi^{2} \alpha$, maka terima $\mathrm{H}_{0}$.

\section{Analisis Vegetasi}

Analisis vegetasi untuk mendapatkan nilai penting (INP) jenis pohon di habitat orangutan dilakukan menurut Soeriane- gara dan Indrawan (1984), di mana INP merupakan penjumlahan antara kerapatan relatif di tiap jenis pohon, frekuensi relatif, dan dominansi relatif.

Untuk mengetahui ukuran keanekaragaman jenis digunakan indeks keanekaragaman Shannon-Wiener (Krebs, 1978; Santosa, 1995) dan indeks kemerataan Hulbert (1971):

\section{a. Indeks Keanekaragaman (H')}

$$
\begin{aligned}
& \mathrm{H}^{\prime}=-\sum\left(\mathrm{p}_{\mathrm{i}} \cdot \operatorname{Lnp}_{\mathrm{i}}\right) \\
& \mathrm{p}_{\mathrm{i}}=\frac{\mathrm{n}_{\mathrm{i}}}{\mathrm{N}}
\end{aligned}
$$

Dimana:

$\mathrm{H}^{\prime}=$ Indeks Keanekaragaman Shannon-Wiener (Shannon Index of Diversity)

$\mathrm{n}_{\mathrm{i}}=$ Indeks Nilai Penting suatu jenis

$\mathrm{N}=$ Jumlah Indeks Nilai Penting seluruh jenis

\section{b. Indeks Kemerataan (Evenness)}

$$
\text { Evenness }=\frac{\mathrm{D}}{\mathrm{D}_{\mathrm{Max}}}
$$

Dimana:

Evenness $=$ Nilai kemerataan $($ antara $0-1)$

D $\quad=$ Nilai indeks keanekaragaman hasil pengamatan

$\mathrm{D}_{\text {Max }}=$ Nilai Max indeks keanekaragaman

Untuk mengetahui urutan preferensi jenis pakan digunakan nilai indeks $\mathrm{Neu}$ (Bibby et al. 1998). Jika indeks seleksi (preferensi) lebih dari $1(\mathrm{w} \geq 1)$ maka jenis pakan yang bersangkutan disukai karena penggunaan (usage) lebih besar daripada ketersediaan (availability).

\section{HASIL DAN PEMBAHASAN}

\section{A. Orangutan yang Menjadi Obyek Penelitian}

Berdasarkan survey pendahuluan, dijumpai lima ekor orangutan dengan komposisi umur dan jenis kelamin: dua ekor jantan dewasa, satu ekor betina dewasa, satu ekor betina dewasa induk, dan satu ekor jantan anak yang selanjutnya akan menjadi fokus penelitian. Untuk mempermudah penyebutan selanjutnya, masingmasing orangután diberi nama. Orangután dan jumlah jam pengamatan dalam penelitian ini disajikan pada Tabel 1. 
Tabel (Table) 1. Jumlah jam pengamatan orangutan di Mentoko, TN Kutai (The Total observation of orangután in Mentoko, Kutai National Park)

\begin{tabular}{llcc}
\hline $\begin{array}{c}\text { Nama orangutan } \\
\text { (Orangutan name })\end{array}$ & $\begin{array}{c}\text { Jenis kelamin dan kelas umur } \\
(\text { Sex and age class) }\end{array}$ & $\begin{array}{c}\text { Jumlah jam pengamatan } \\
\text { (Total hour observation) }\end{array}$ & $\begin{array}{c}\text { Tanggal pengamatan } \\
\text { (Date of observation) }\end{array}$ \\
\hline Dewi & Betina dewasa (Adult female) & 156,52 & 26 Mei-07 Juni 2007 \\
Dewa & Jantan dewasa (Adult male) & 158,20 & 26 Mei-07 Juni 2007 \\
Ayu & Betina dewasa-induk (Adult & 182,87 & 27 Mei-10 Juni 2007 \\
& female- mother) & & \\
Tole & Jantan anak (Infant male) & 182,87 & 27 Mei-10 Juni 2007 \\
Surya & Jantan dewasa (Adult male) & 109,83 & 29 Mei-06 Juni 2007 \\
\hline Jumlah (Totally) & & 790,29 & \\
\hline
\end{tabular}

\section{B. Komposisi Vegetasi}

Berdasarkan analisis vegetasi didapatkan 51 jenis pohon yang tercakup dalam 25 famili, 36 jenis tiang dari 19 famili dan 39 jenis pancang dari 22 famili. Jenis pohon yang paling banyak ditemukan di habitat orangutan adalah ulin (Eusideroxylon zwageri) dan merupakan jenis tumbuhan dengan INP terbesar yaitu 21,59, sengkuang (Dracontomelon dao), laban (Vitex pubescens), medang (Litsea sp.), bayur (Pterospermum diversifolium), maligara (Dillenia borneensis), katan (Dysoxylum sp.), kenanga (Cananga odorata), simpur (Dillenia excelsa), dan teja (Ptenandra sp.). Kerapatan pohon di habitat orangutan adalah 167 pohon/ha dengan indeks keanekaragaman jenis 3,75 dan indeks kemerataan 0,95.

\section{Pola Penggunaan Ruang}

\section{Sebaran Spasial Aktivitas pada Struktur Vertikal}

Aktivitas orangutan lebih banyak dilakukan pada ketinggian antara 20-30 m dari permukaan tanah (Gambar 1). Dewi, hampir 82,58\% dari seluruh waktu aktivitas hariannya dilakukan pada ketinggian ini, sedangkan aktivitas pada ketinggian di bawah $20 \mathrm{~m}$ dan di atas $30 \mathrm{~m}$ masingmasing sebesar $17 \%$ dan 0,27\%. Demikian juga dengan Ayu sebanyak 80,43\% pada ketinggian $20-30 \mathrm{~m}, 19 \%$ pada ketinggian di bawah $20 \mathrm{~m}$, dan tidak pernah dijumpai pada ketinggian di atas 30 m. Selanjutanya Dewa, sebesar $79 \%$, $20 \%$, dan $0,83 \%$, Surya sebesar $76 \%$, $22 \%$, dan $2 \%$, Tole sebesar $72 \%, 28 \%$, dan sama seperti induknya, tidak pernah dijumpai beraktivitas pada ketinggian di atas $30 \mathrm{~m}$.

Pada Gambar 2 terlihat bahwa aktivitas orangutan terdistribusi secara tidak merata pada masing-masing ketinggian yaitu pada ketinggian di bawah $20 \mathrm{~m}$, antara 20-30 m, dan pada persentase yang sangat kecil pada ketinggian di atas $30 \mathrm{~m}$.

Pada aktivitas makan, proporsi waktu terbanyak dijumpai pada ketinggian 20$30 \mathrm{~m}$ di atas permukaan tanah. Berkisar antara $75-88 \%$ aktivitas makan dilakukan pada ketinggian ini, sedangkan pada ketinggian di bawah $20 \mathrm{~m}$ hanya berkisar $12-25 \%$. Demikian juga dengan aktivitas beristirahat lebih banyak dijumpai pada ketingian tertentu. Berkisar 81-96\% aktivitas isirahat dijumpai pada ketinggian 20-30 m. Sisanya sebesar 2-19\% pada ketinggian di bawah $20 \mathrm{~m}$. Pada ketinggian di atas $30 \mathrm{~m}$ tercatat hanya Surya yang dijumpai dengan persentase waktu $2 \%$.

Berdasarkan uji khi-kuadrat pada tingkat signifikansi 0,05 terbukti bahwa ada hubungan antara ketinggian tempat dengan jenis aktivitas orangutan. Nilai khi-kuadrat ${ }^{2}$ hitung $=58,22$, sedangkan dengan derajat bebas $(\mathrm{df})=8$ dan tingkat signifikansi 0,05 nilai ${ }^{2}$ tqbel adalah 15,507 yang menunjukkan bahwa ketinggian tempat berpengaruh nyata terhadap aktivitas orangutan. Tempat pada pohon yang paling disukai untuk beraktivitas adalah pada ketinggian $20-30 \mathrm{~m}$ dari permukaan tanah (72,01-82,58\%). Demikian juga dengan distribusi jenis 


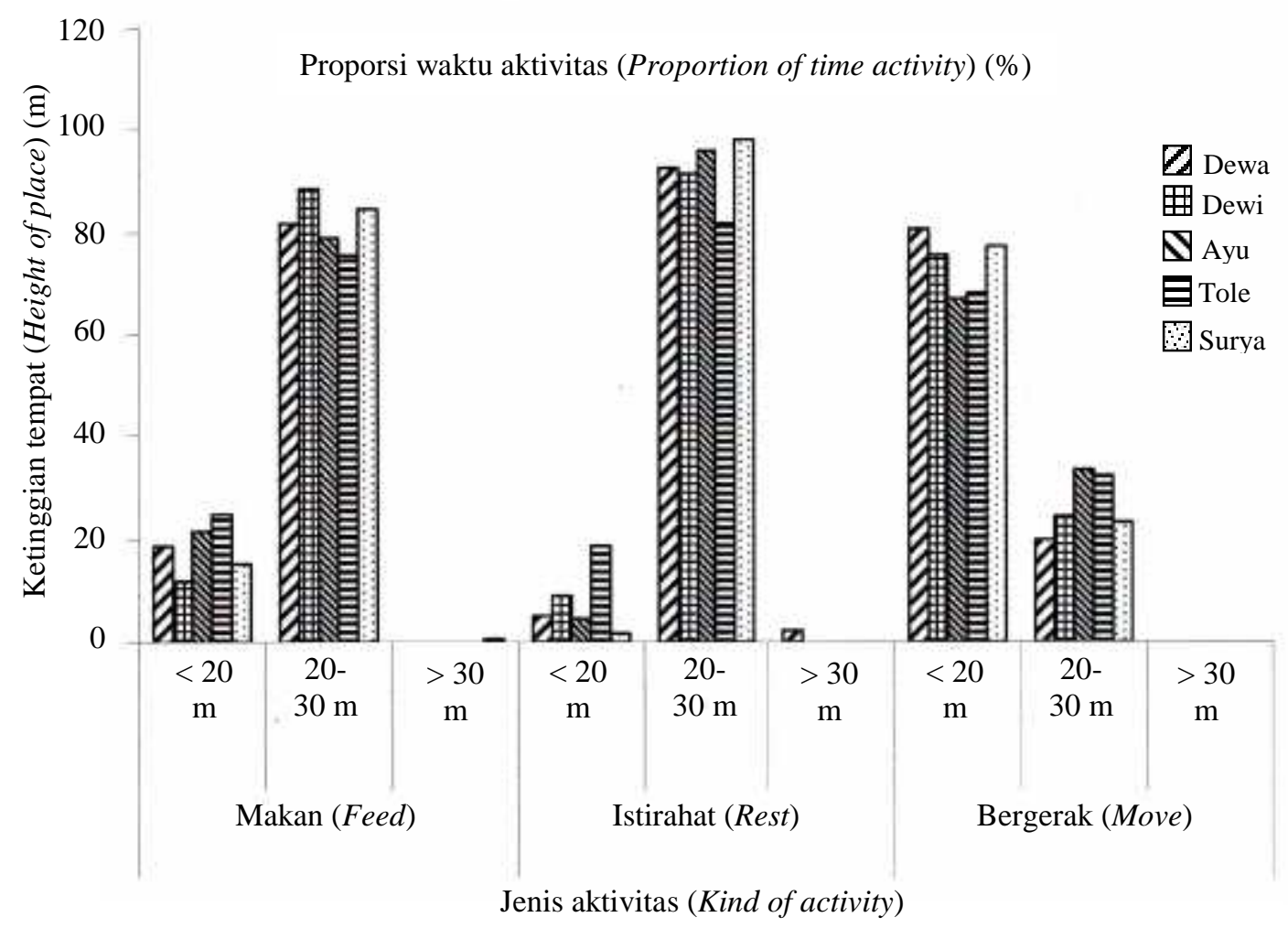

Gambar (Figure) 1. Proporsi waktu aktivitas berdasar periode pengamatan (Proportion of time activity base on observation period)

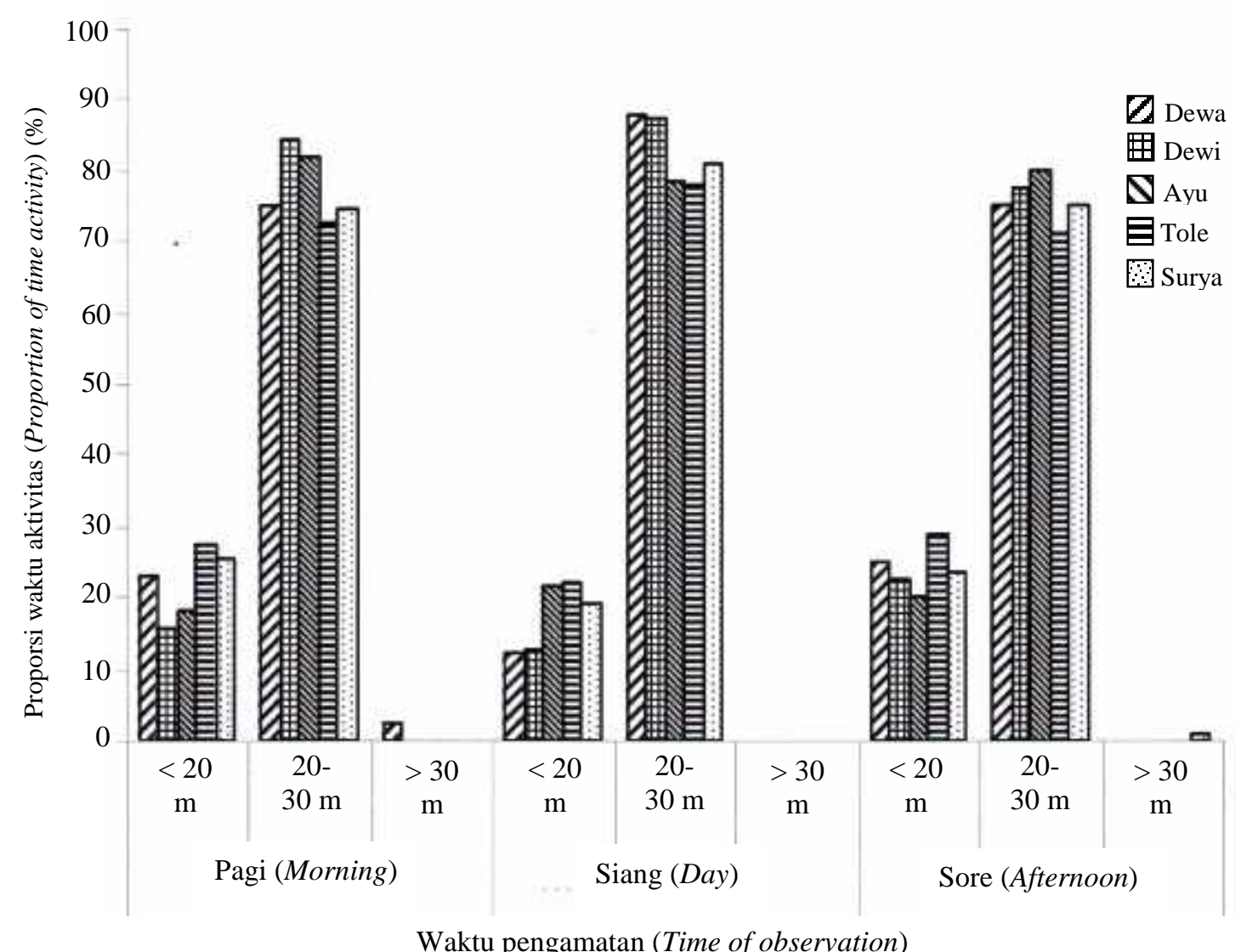

Gambar (Figure) 2. Proporsi waktu aktivitas berdasar ketinggian tempat (Proportion of time activity base on height of place) 
aktivitas dan ketinggian tempat, secara signifikan bahwa aktivitas makan dan istirahat terjadi secara dominan pada ketinggian 20-30 m.

\section{Pola Pergerakan dan Jarak Jelajah Orangutan}

Ayu mempunyai jarak jelajah terpendek di antara orangutan lain yaitu rata-rata $0,74 \mathrm{~km}$ per hari, dengan kisaran antara $0,65-0,80 \mathrm{~km}$ per hari. Selanjutnya Dewi dan Dewa mempunyai jarak jelajah rata-rata $0,90 \mathrm{~km}$ per hari, dengan kisaran antara 0,82-1,17 km per hari. Surya mempunyai jarak jelajah rata-rata 0,96 $\mathrm{km}$ per hari, dengan kisaran antara 0,86$1,11 \mathrm{~km}$ per hari.

\section{Pohon Tempat Bersarang}

Untuk mengetahui jenis pohon yang disukai orangutan sebagai tempat membuat sarang digunakan asumsi bahwa semakin tinggi frekuensi jenis pohon tertentu digunakan, maka pohon tersebut semakin disukai. Selanjutnya untuk menganalisis hubungan antara frekuensi dengan jenis pohon dilakukan dengan pendekatan Metode Neu's (indeks preferensi).

Berdasarkan Tabel 2 dapat diketahui bahwa dari tujuh jenis pohon yang dijadikan tempat bersarang selama penelitian, hanya satu jenis saja yang benar-benar disukai oleh orangutan yaitu pohon kenanga (Canangium odorotum). Hal ini ditunjukan dengan $w>1$, sebagaimana Bibby et al. (1998) dalam Gunawan (2004) menyatakan bahwa jika $\mathrm{w}_{1}>1$, maka pilihan satwa terhadap sesuatu itu karena satwa menyukainya. Dengan demikian orangutan memilih pohon kenanga untuk membuat sarang karena pohon kenanga disukai walaupun jumlah pohon ini relatif sedikit sedangkan jenis-jenis lain tetap digunakan sebagai tempat untuk membuat sarang dalam porsi penggunaan yang rendah.

Tabel (Table) 2. Indeks Neu's untuk preferensi jenis pohon tempat bersarang (Index Neus's for preference of species of tree for making).

\begin{tabular}{|c|c|c|c|c|c|c|}
\hline \multirow[b]{2}{*}{$\begin{array}{c}\text { Jenis Pohon (Species of } \\
\text { tree })\end{array}$} & \multicolumn{2}{|c|}{$\begin{array}{l}\text { Ketersediaan } \\
\text { (Availability) }\end{array}$} & \multicolumn{2}{|c|}{$\begin{array}{l}\text { Penggunaan } \\
\text { (Use) }\end{array}$} & \multicolumn{2}{|c|}{$\begin{array}{c}\text { Indeks preferensi } \\
\text { (Preferention indeks) }\end{array}$} \\
\hline & $\begin{array}{c}\text { Kerapatan } \\
\text { (Density) } \\
\text { per ha } \\
\end{array}$ & $\begin{array}{c}\text { Proporsi } \\
\text { (Proportion) } \\
\text { (a) }\end{array}$ & $\begin{array}{c}\mathrm{Jml} \\
(\mathrm{Num}) \\
(\mathrm{n}) \\
\end{array}$ & $\begin{array}{c}\text { Proporsi } \\
\text { (Proportion) } \\
\text { (r) }\end{array}$ & (w) & (b) \\
\hline $\begin{array}{l}\text { Kenanga (Cananga } \\
\text { odorata) }\end{array}$ & 4,69 & 10,715 & 16 & 32,000 & 2,986 & 0,544 \\
\hline $\begin{array}{l}\text { Ulin (Eusideroxylon } \\
\text { zwageri) }\end{array}$ & 10,94 & 24,994 & 12 & 24,000 & 0,960 & 0,175 \\
\hline $\begin{array}{l}\text { Sengkuang } \\
\text { (Dracontomelon dao) }\end{array}$ & 9,4 & 21,476 & 9 & 18,000 & 0,838 & 0,153 \\
\hline $\begin{array}{l}\text { Maligara (Dillenia } \\
\text { borneensis) }\end{array}$ & 6,25 & 14,279 & 5 & 10,000 & 0,700 & 0,128 \\
\hline Baleo (Diospyros sp.) & 3,12 & 7,128 & 3 & 6,000 & 0,842 & 0,153 \\
\hline $\begin{array}{l}\text { Bayur (Pterospermum } \\
\text { diversifolium) }\end{array}$ & 6,25 & 14,279 & 4 & 8,000 & 0,560 & 0,102 \\
\hline $\begin{array}{l}\text { Kayu arang (Diospyros } \\
\text { borneensis) }\end{array}$ & 3,12 & 7,128 & 1 & 2,000 & 0,281 & 0,051 \\
\hline Jumlah (Totally) & 43,77 & 100,000 & 50 & 84,00 & 5,49 & 1,000 \\
\hline
\end{tabular}

Keterangan (Remark) :

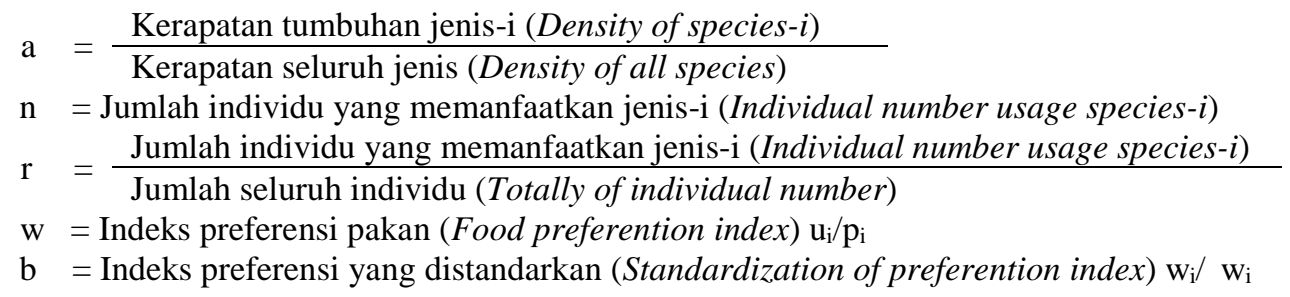




\section{Perilaku Makan dan Preferensi Makanan Orangutan}

Tingkat kesukaan orangutan terhadap jenis makanan dapat diketahui melalui proporsi waktu yang digunakan untuk memakan suatu jenis makanan. Sesuai dengan hasil pengamatan, jenis makanan orangutan dapat dibagi menjadi tiga kategori yaitu buah, daun, kulit kayu (kulit pohon dan liana), dan lain-lain (bunga, kuncup).

Dari semua jenis makanan yang teramati dimakan orangutan, buah menempati proporsi tertinggi dengan rata-rata persentase $63,2 \%$; selanjutnya daun $26,2 \%$; kulit kayu $8,48 \%$; dan lainlain $4,5 \%$. Jantan yang belum dewasa memakan buah yaitu 66\%, sedangkan kebiasaan jantan dewasa makan buah yang dalam porsi sama antara $62-63 \%$. Selanjutnya proporsi untuk daun persentase tertinggi juga ditempati oleh Tole yaitu $32 \%$, sedangkan orangutan lain berkisar antara 23-26\%. Persentase ini tidak berbeda jauh dengan orangutan di Bahorok, di antara berbagai jenis makanan menurut Sinaga (1992), buah menduduki persentase yang tertinggi dengan rata-rata 55,6\%, menyusul daun $35,3 \%$, dan sisanya untuk jenis makanan lain. Menurut Meijaard dan Rijksen (1999), di habitat yang berkualitas baik, antara 57\% (jantan) dan $80 \%$ (betina) waktu makannya dihabiskan untuk memakan buahbuahan.

\section{Pola Penggunaan Waktu}

Lama waktu aktif rata-rata harian orangutan adalah 12 jam 7 menit dengan kisaran antara 11 jam 42 menit sampai 12 jam 40 menit. Dewa, rata-rata lama waktu aktif hariannya adalah 12 jam 10 menit, Surya selama 12 jam 12 menit, Dewi selama 12 jam 12 menit, dan Ayu beserta anaknya selama 12 jam 11 menit.

\section{Alokasi Penggunaan Waktu Harian}

Proporsi waktu aktivitas makan Dewi paling tinggi dibanding orangutan lain yaitu $46 \%$, beristirahat $43 \%$, dan bergerak $10 \%$. Selanjutnya Dewa persentase aktivitas makan 46\%, bergerak 13\%, beristirahat $31 \%$. Ayu mengalokasikan waktunya untuk makan sebesar $45 \%$, istirahat $44 \%$, bergerak 10\%. Surya, aktivitas makan sebesar $44 \%$, istirahat $42 \%$, dan bergerak $11 \%$. Tole, aktivitas makan sebesar $41 \%$, istirahat $36 \%$, bergerak $11 \%$, dan $20 \%$ untuk bermain.

Persentase waktu makan, bergerak, dan berisirahat orangutan di Mentoko menunjukkan perbedaan yang relatif kecil. Misalnya rata-rata proporsi waktu untuk makan adalah $47 \%$ dengan kisaran antara $41 \%$ pada Tole sampai $46 \%$ pada Dewi. Hal ini sesuai dengan hasil penelitian Rodman (1973) di Kutai yang menyatakan bahwa persentase aktivitas makan orangutan adalah 46\%. Di Bahorok, jantan pra dewasa menghabiskan waktunya untuk makan dalam sehari $50 \%$, jantan dewasa 39\%, dan induk betina 32\% (Sinaga, 1992). Menurut Djojosudharmo (1978) orangutan di Ketambe rata-rata aktivitas makan berkisar antara 4,6-7,6 jam setiap hari.

Pada siang hari aktivitas yang dominan adalah beristirahat, kondisi cuaca yang cenderung panas pada siang hari menyebabkan orangutan mengurangi aktivitas makan dan bergerak. Berdasarkan lama keaktifan hariannya, orangutan di Mentoko menghabiskan waktu ratarata 12 jam 10 menit dengan kisaran antara 11 jam 27 menit sampai 12 jam 38 menit. Permulaan keaktifan orangutan berada pada kisaran jam 05.35-06.41, sedangkan mengakhiri aktivitasnya pada sore hari berada pada kisaran jam 17.4418.25. Hasil penelitian Sinaga (1992) menyebutkan bahwa orangutan di Bahorok menghabiskan waktu rata-rata 12 jam 25 menit dengan kisaran 12 jam 22 menit sampai 12 jam 58 menit, sedangkan Djojosudharmo (1978) menyebutkan bahwa orangutan di Ketambe memulai keaktifan harian sejak jam 06.00 dan diakhiri jam 18.00 . 
Berdasarkan uji khi-kuadrat pada tingkat signifikansi 0,05 menunjukkan tidak adanya perbedaan dalam penggunaan waktu oleh masing-masing individu. Nilai khi-kuadrat ${ }^{2}$ hitung $=6,763$, sedangkan dengan derajat bebas $(\mathrm{df})=8$ dan tingkat signifikansi 0,05 nilai ${ }^{2}$ tabel adalah 15,507. Karena ${ }^{2}$ hitung lebih kecil dari 2 tabel, menunjukkan bahwa secara statistik, dalam pengalokasian waktu untuk aktivitas makan, bergerak, dan istirahat tidak ada perbedaan yang signifikan. Proporsi rata-rata aktivitas makan sebesar $44,65 \%$, untuk istirahat dan bergerak masing-masing $41,9 \%$ dan $11,4 \%$. Berdasarkan penelitian terhadap orangutan di Bahorok, Sinaga (1992) melaporkan bahwa jantan dewasa, waktu untuk aktivitas makan sebesar 39,2\% dan istirahat $41,6 \%$. Aktivitas makan betina induk $32,5 \%$ dan istirahat $52,3 \%$, sedangkan jantan pra dewasa, aktivitas makan sebesar 50,4\% dan istirahat 23,3\%.

\section{Sebaran Temporal Aktivitas}

Sebaran temporal aktivitas dipengaruhi oleh distribusi sumber pakan dalam hutan. Apabila di sekitar sarang terdapat pohon buah, biasanya aktivitas makan akan dimulai sesaat setelah orangutan bangun tidur, namun apabila tidak terdapat pohon buah, maka orangutan akan bergerak mencari sumber pakan terdekat. Aktivitas makan paling tinggi terjadi pada pagi, sedangkan pada siang hari orangutan lebih banyak menggunakan waktunya untuk istirahat.

Sebaran temporal aktivitas terdistribusi secara tidak teratur sepanjang waktu pengamatan, namun pada masing-masing individu maupun antar individu secara temporal aktivitasnya terpola sepanjang hari.

\section{KESIMPULAN DAN SARAN}

\section{A. Kesimpulan}

1. Dalam melakukan aktivitas harian orangutan lebih banyak menempati kisaran ketinggian tertentu dari permukaan tanah. Sebanyak 76-82\% aktivitasnya dilakukan pada kisaran ketinggian $20 \mathrm{~m}$ dan $30 \mathrm{~m}$ dari permukaan tanah. Pada kisaran ketinggian ini orangutan melakukan aktivitas makan, bergerak, istirahat, dan membuat sarang. Berdasarkan uji khi-kuadrat pada tingkat signifikansi 0,05 dengan nilai khi-kuadrat 2 hitung $=58,22$ terbukti bahwa ada hubungan antara ketinggian pada pohon dengan distribusi aktivitas orangutan.

2. Jarak tempuh harian terpendek orangutan $0,74 \mathrm{~km}$ sehari dan yang terpanjang $0,90 \mathrm{~km}$ per hari, dengan kisaran 0,82-1,17 km sehari.

3. Pengalokasian waktu aktivitas makan, bergerak, dan istirahat antar individu tidak ada perbedaan yang signifikan $(\chi 2=6,763$ dan $\mathrm{p}<0,05)$. Demikian juga dalam pengalokasian aktivitas berdasarkan periode waktu pagi, siang, dan sore. Masing-masing dengan nilai 2 hitung $=7,590$, 2,027, dan 2,053 lebih kecil dari nilai ${ }^{2}$ tabel $=15,507$.

4. Sebaran temporal aktivitas harian orangutan terdistribusi secara tidak teratur di sepanjang waktu aktif harian di siang hari, namun secara umum terpola sepanjang hari.

5. Habitat orangutan di Mentoko adalah hutan sekunder. Dari hasil analisis vegetasi didapatkan 51 jenis pohon yang tercakup dalam 25 famili, 36 jenis tiang dari 19 famili dan 39 jenis pancang dari 22 famili. Jenis pohon yang banyak ditemukan di habitat orangutan adalah sengkuang (Dracontomelon dao), laban (Vitex pubescens), medang (Litsea sp.), bayur (Pterospermum diversifolium), maligara (Dillenia borneensis), katan (Dysoxylum sp.), kenanga (Cananga odorata), simpur (Dillenia excelsa), dan teja (Ptenandra sp.). Kerapatan pohon di habitat orangutan adalah 
167 pohon/ha dengan indeks keanekaragaman jenis adalah 3,75 dan kemerataan jenis adalah 0,95 .

\section{B. Saran}

Untuk kepentingan konservasi orangutan maka perlu dilakukan hal-hal sebagai berikut:

1. Meningkatkan perlindungan kawasan dan habitat orangutan agar vegetasi pohon sebagai komponen ruang yang penting untuk aktivitas orangutan dapat dipertahankan.

2. Melakukan rehabilitasi pada kawasan hutan bekas terbakar dengan jenisjenis pohon pakan orangutan.

3. Melakukan pengelolaan habitat orangutan yang berada di luar kawasan konservasi.

\section{DAFTAR PUSTAKA}

Bibby, C., S. Marsden and A. Fielding. 1998. Bird-habitat studies. The expedition advisory centre. Royal Geographical Society. London.

Djojosudharmo, S. 1978. Beberapa aspek tingkah laku orangutan (Pongo pygmaeus Linne. 1760). Universitas Nasional Jakarta. Jakarta.

Gunawan, H. 2004. Preferensi dan konsumsi pakan anak burung maleo (Macrocephalon maleo Sal Muller.) dalam masa penyapihan. Jurnal Penelitian Hutan dan Konservasi Alam I(1): 58-66. Pusat Penelitian dan Pengembangan Hutan dan Konservasi Alam. Bogor.
Krebs, J.C. 1978. Ecology: the experimental analisis of distribtion and abundance. Harper and row publisher. New York.

Meijaard, E., D.H. Rijksen, dan N.S. Kartikasari. 1999. Di ambang kepunahan kondisi orangutan liar di awal abad ke-21. The Gibbon Foundation Indonesia.

Meijaard, E. dan N. Makinudin. 2007. Orangutan menghadapi kepunahan. www.orangutan.com.

Rijksen, H.D. 1978. A field study on sumatran orangutans (Pongo pygmaeus abelii Lesson, 1827). Ecology, Behaviour and Concervation. Agricultural University, Wageningen. Netherlands.

Rodman, P. 1973. Population compotition and adaptive organization among orangutans. In: Comparative Ecology and Behavior of Primates, J. Crook and Michael (eds). Academic Press, London.

Santosa, Y. 1995. Konsep ukuran keanekaragaman hayati di hutan tropika. Jurusan Konservasi Sumberdaya Hutan, Fakultas Kehutanan IPB. Bogor.

Sinaga, T. 1992. Studi habitat dan perilaku orangutan (Pongo pygmaeus abelii) di Bohorok Taman Nasional Gunung Leuser. Tesis Fakultas Pascasarjana Institut Pertanian Bogor. Tidak Dipublikasikan.

Soerianegara, I. dan A. Indrawan. 1988. Ekologi hutan Indonesia. Jurusan Manajenen Hutan, Fakultas Kehutanan IPB. Bogor. 